\title{
Coupling between Geothermal Energy and Solar Energy for Creation of New Energetic System "Production of Electricity and Hydrogen" in Intelligent Buildings
}

\author{
C. Ameur Menad, R.Gomri \\ Climatic Department, \\ University Mentouri \\ Constantine,
}

Algeria.

\begin{abstract}
This paper describes a new technique coupling between two mains parts which are geothermal energy and solar energy in order to product electricity and to create a comfort in intelligent buildings. The first parts consists extraction of heat water from geothermal source at the temperature of $95^{\circ} \mathrm{C}$ (Guelma), for injecting it in solar panels in order to increase the temperature of the water until $600^{\circ} \mathrm{C}$ for production of electricity and hydrogen. Moreover, the selection of geothermal energy is for only two reasons. In one hand; is to generate heating system in winter and cooling system used by absorption machine in summer. In the other hand is to develop of the local production of electricity and hydrogen at the same time. Finally the principal objective is to provide energy efficiency in intelligent buildings and distribution of electricity in the grid. Another aim is to minimize loads during production of electricity.
\end{abstract}

\section{Keywords}

energy efficiency, intelligent buildings, production of electricity, geothermal energy, solar energy, production of hydrogen.

\section{INTRODUCTION}

Local production of electricity and hydrogen from different energetic sources was studied in three analytical cases for increasing the level of the energy efficiency in intelligent buildings. However, the application of renewable energy was proposed in all studied cases, but the best solution is coupling between many sources of sustainable energy for many advantages as minimization of the cost during consumption of energy. Considered the outlet temperature obtained is varied between $95^{\circ} \mathrm{C}$ and $600^{\circ} \mathrm{C}$, in other cases is more to apply it in many energetic systems. The production of high temperature is for production of hydrogen but in the studies cases is limited for production of electricity, so the results of this work will be apply it in future work for production of hydrogen at different temperature by coupling between geothermal energy and solar energy. The future energetic systems in intelligent buildings are not for production of electricity only, but for production of hydrogen also. Many studies about different renewable energy especially photovoltaic energy were studied. An experimental measurement to study the solar irradiation in sunny and cloudy days to understand the amount of irradiance in all seasons was developed by Nelson A. Kelly Thomas L. Gibson [1]. The obtained results explain that on sunny days the amount of solar energy is very higher when cosine of the angle between direct and incident radiation is known, especially by the application of DTS (directly toward the sun) configuration. On cloudy days; the obtained results explain that $40 \%$ of energy capture was increasing by the application of the method horizontal $\mathrm{H}$ configuration. Another work about studies of irradiation characteristic for developing the technical parameters of photovoltaic solar panels installed on the roof of buildings (in Andalusia-Spain-) in order to product and distribute of the electricity was developed by j, Ordonez' and al [2]. R. Crook and al [3] were developed a new simulation method for creation a hybrid panels by combination between solar thermal energy and photovoltaic energy and phase change material system. Considered the application of wind energy for production of electricity, Ezio Sesto, Claudio Casale,* [4] were studied the generation of electricity by using of wind energy in basic case. James R. Salmon, and al [5] introduced two models between speed direction and energy produced estimate. Jeffrey Swofford, Michael Slattery [6] were studied the production of electricity by using of wind energy in Texas (USA), to understanding the relation between production of wind energy and public. Another kink of renewable energy (geothermal energy) was discussed by Stuart J. Self and al [7] for minimize consumption of energy, cost and emission of $\mathrm{CO} 2$ during generation of heat pumps. However, Onder Ozgener, and al [8] were studied the exergoeconomic for evaluated the performance of geothermal heat pumps. Finally Hacene Mahmoudi and al [9], were studied the desalination of sea water by the application of geothermal energy in Algeria because there many available sources. Concerning the contribution of this research is to develop a new technique for production of the electricity which by using coupling between the two kinds of renewable energy for producing of hydrogen and for increasing the energy efficiency in intelligent buildings. However; the first part of the proposal system is to the extract the heat water at the temperature of $95^{\circ} \mathrm{C}$ from the geothermal source (exactly in Guelma it's located in the east of Algeria) in order to create comfort and product of electricity. Concerning the study of air conditioning system; an absorption machine $\left(\mathrm{BrLi} / \mathrm{H}_{2} \mathrm{O}\right)$ was generated by the geothermal source which minimizes all the amount of energy Consumed for production of cool water. In the other hand; generation of heating systems by using of geothermal energy will minimize all amount of energy Consumed by the heat pump. The process of coupling between of geothermal energy and solar is shown in fig1.

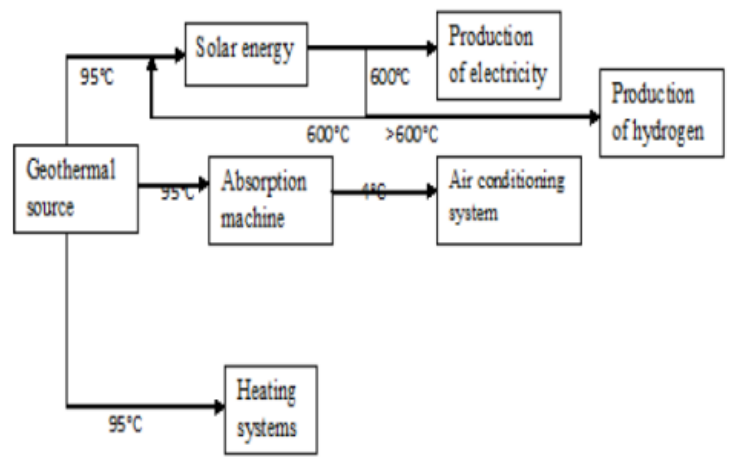


Fig 1: coupling between solar energy and geothermal energy for creation of comfort and production of electricity (hydrogen also).

\section{Study of proposed cases}

Three analytical studies cases about application of photovoltaic solar panels were proposed to increase the temperature of vapor water from $95^{\circ} \mathrm{C}$ to $600^{\circ} \mathrm{C}$. There is more than one panel in each studied cases, for this reason we calculated the outlet temperature until the last panel (arrives to $600^{\circ} \mathrm{C}$ ). Fig 2 explains the first case; which is describing the position of circular channels between two photovoltaic panels. The objective of circular channel is to ensure circulation of vapor water (fluid for production of electricity), each electrical cell produced amount of electricity which we distributed it in two similar resistances. All the amount of electricity produced by the different electrical resistances was absorbed by the vapor water in order to increasing the outlet temperature. In this case photovoltaic panels for production amount of $300 \mathrm{~W}$ was selected.

Outlet vapor water

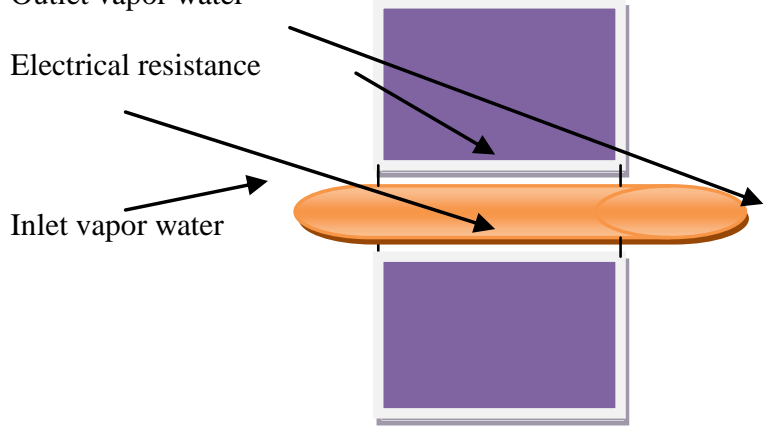

Fig 2: increase the temperature of the vapor water by using of the photovoltaic cells.

Concerning the second case; a photovoltaic solar panels was coupled with the wind energy and geothermal energy. The fig $\mathbf{2}$, describe the application of a photovoltaic solar panels for increase the temperature of the vapor water and production of the electricity at the same time. Each solar panel is composed of two parts; the first is photovoltaic cells for production of electricity (similar of the first model), the second part is circular channels connected with a wind turbine blade in order to rotate the channels for rotation of the small electrical generator. An electrical resistance will be absorbed all amount of electricity energy produced by the small generator for using it to increase the outlet temperature of the vapor water.

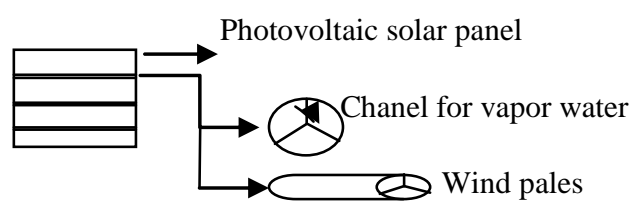

Fig 3: coupling between the wind energy, geothermal energy and solar energy for production of electricity and increasing of the outlet temperature.

For more detail about the second model; the fig 4 explains the objective of coupling between different sources of renewable energy. The proposal installation used channels with different diameter from the biggest in the first panel to the smaller in the last panel. The aim of wind energy is to ensure the rotation of the channels; I.E the vapor water causes the rotation of the wind pals connecting the channels, so automatically rotation of channels. The source of electricity produced by small generator was considered as a result of channels rotation due to the passage of vapor water with high celerity which was extracted from geothermal source. However the celerity of vapor water is related with increasing of the temperature and minimization of the diameter because the flow is constant. The aim of channels rotation is to rotate the small generator for production of electricity; the amount of electricity produced by small generator will increase the temperature of vapor water in the next photovoltaic solar panel by contact between electric resistances and the vapor water. The operation will repeat until the outlet temperature arrives to $600^{\circ} \mathrm{C}$. The small generator will storage the amount of electricity when the temperature arrives to $600^{\circ} \mathrm{C}$, so there are two sources to product the electricity which are photovoltaic and rotation of a small generator. The outlet vapors at $600^{\circ} \mathrm{C}$ will product the electricity by rotation of a big turbine at the end of the installation. The flowing figure (fig 4) depicts the process of electricity production by coupling between three renewable energy, which are photovoltaic solar, geothermal and wind energy (The aim of this model is to clarify that production of electricity were produced in three regions).

Outlet temperature

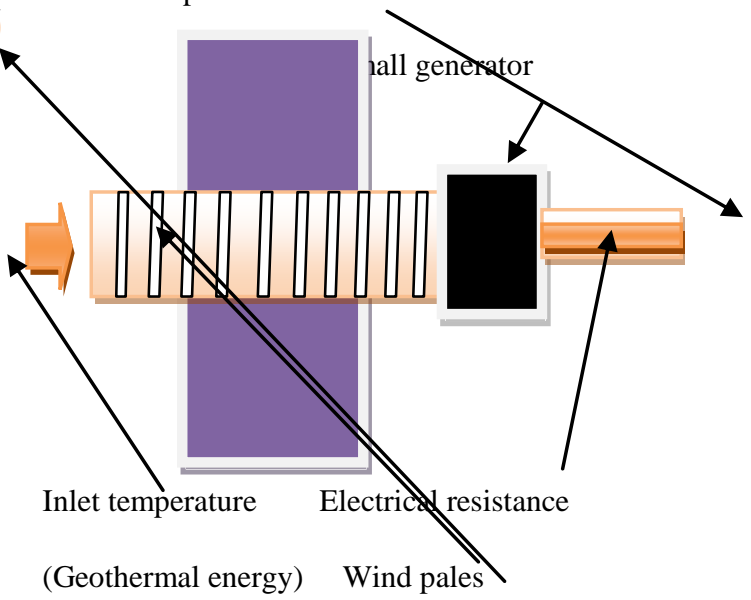

Fig 4: production of electricity by coupling between three sources of renewable energy (geothermal, wind, photovoltaic) for increasing the temperature of vapor water.

Finally; the third studies case is similar as the second case, however there is a mini turbine for production of electricity which is generated by the flow of vapor water. The study of the third case is just to distinguish between the production of electricity by small generator and mini turbine to gain more amount of electricity and increasing of the temperature of vapor water for production of electricity in the biggest turbine at the end of the installation.

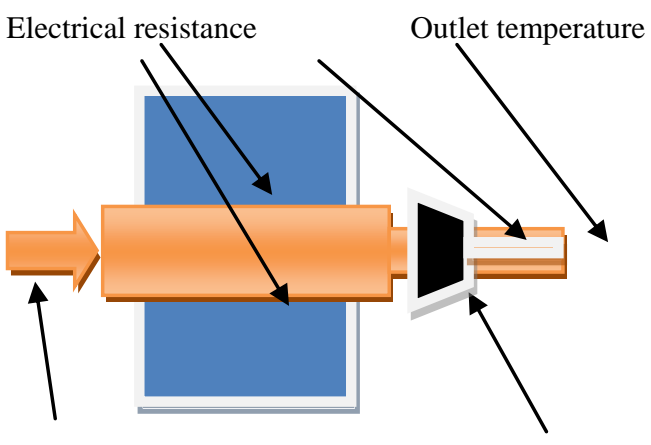


Inlet temperature Mini turbine

Fig 5: coupling between the photovoltaic energy and geothermal energy for production of electricity with mini turbine and increasing of vapor water.

\section{Analytical study of the photovoltaic solar panels}

\subsection{The first model}

Concerning the first model; the following equation represents the outlet temperature from the photovoltaic solar panel:

$\mathrm{T}_{\mathrm{s}}=\mathrm{T}_{\mathrm{e}}+\left(\mathrm{P}_{\mathrm{sg}} / \mathrm{m} \cdot \mathrm{Cp}\right)$

Where; Ts, Te, m, Cp, Psg: are respectively outlet temperature $\left({ }^{\circ} \mathrm{C}\right)$, inlet temperature $\left({ }^{\circ} \mathrm{C}\right)$, the flow of the vapor water $(\mathrm{m} 3 / \mathrm{s})$, specific heat of the vapor water $(\mathrm{J} / \mathrm{kg} . \mathrm{K})$, electrical power generate by the solar photovoltaic panel (in the studies case $\mathrm{Psg}=300 \mathrm{~W}$ ).

\subsection{The second model}

Concerning the second model; the flow of vapor water is constant with the increasing of the temperature, however the section is decrease from the first panel to the final panel. Many hypotheses were proposed to simplify the calculation such as, the flow of the vapor water; the inlet temperature, celerity and the section of the channel are known. The angular celerity of the first cannel to rotate the first small generator is known by:

$$
\mathrm{v}=\mathrm{R} \cdot \omega
$$

Where; $\omega, \mathrm{R}, \mathrm{v}$ are respectively the angular celerity $(\mathrm{rad} / \mathrm{s})$, the radius of the channel $(\mathrm{m})$, the linear celerity $(\mathrm{m} / \mathrm{s})$.

The rotation of the channel will cause the production of the electricity for increasing the temperature of the vapor water. The first angular celerity is the low value due to the biggest section and all small generators installed are similar. The amount of the electricity energy produced by the small generator will

absorbed directly by the resistance and it equal to the amount of thermal energy produced between the beginning and the end of the channels. The flowing equation depicts the value of the outlet temperature using the small generator:

$\mathrm{Ts}=\mathrm{n} . \mathrm{k} \cdot \phi \cdot \omega$

Where, $n, k, \phi, \omega$, are represented respectively number of spire of the resistance, constant depended to the characteristics of the motor used, the maximum flux magnetic (Wb), Angular celerity $(\mathrm{rad} / \mathrm{s})$.

\subsection{The third model}

The electrical power produced by the mini turbine is shown in the following equation:

$$
\mathrm{Pu}=0,97 \cdot 9,81 \cdot \mathrm{n}_{\mathrm{t}} \cdot \mathrm{n}_{\mathrm{g}} \cdot \mathrm{Q}_{\mathrm{t}} \cdot \mathrm{H}_{\mathrm{n}}
$$

Where; Pu, Qt, Hn, nt, ng represent respectively the amount of energy produced $(\mathrm{W})$, the flow of the mini turbine $(\mathrm{m} 3 / \mathrm{s})$, net drop $(\mathrm{m})$, the efficiency of the mini turbine, efficiency of the generator (generator of the mini turbine). The following equation show the net drop :

$\mathrm{H}_{\mathrm{n}}=\mathrm{H}_{\mathrm{b}}-\sum \mathrm{H}_{\mathrm{L}}-\frac{\mathrm{V}^{2}}{2 \cdot \mathrm{g}}$
Where, Hb, HL, v, g, represent respectively Gross drop, higher, celerity, acceleration (HL represent about $10 \%$ To $15 \%$ of $\mathrm{Hb}$ ).

The outlet temperature is depicts in the following equation:

$\mathrm{Ts}=\mathrm{Te}+(\mathrm{Pu} / \mathrm{m} . \mathrm{Cp})$

Where Ts, Te, m, Cp, Pu: are respectively outlet temperature, inlet temperature, specific heat, electrical power of vapor water between the inlet and outlet point of each channel connected on the solar panel.

\section{Results and discussions:}

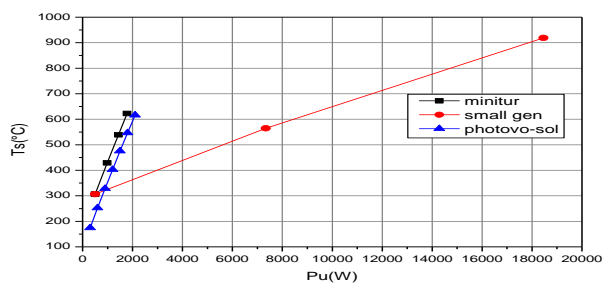

Fig 6: variations of outlet temperature of vapor water with variation of the electrical power.

The increasing of the electrical power causes the increase of the outlet temperature of vapor water. Most of the values of the outlet temperature are varied between $200^{\circ} \mathrm{C}$ and $630^{\circ} \mathrm{C}$, only the first point of the first model and the third point of second model. Considered the first model; the difference between different outlet temperature of vapor water is almost identical due to the section and the celerity are constant. However it is not the same case in the second and the third cases. Concerning the final point of the second model, the outlet temperature is very higher than $600^{\circ} \mathrm{c}$ because the electrical power produced is very important and more than $18000 \mathrm{~W}$. Each point of the different studied cases represent panel.

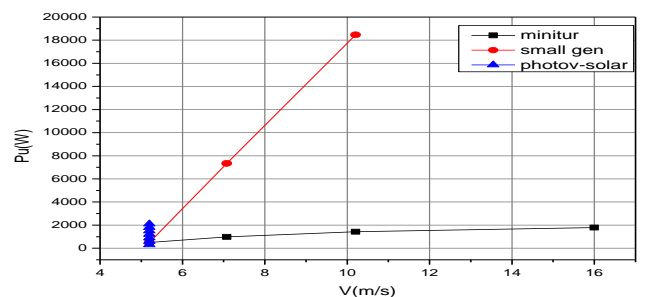

Fig 7: variation of electrical power with celerity of vapor water in channels.

The fig 7 explains the increasing of the electrical power with increasing of celerity of vapor water in channels. Considered the second model (small generator), increasing of the amount of electricity produced is an addition between two sources of energy which are from photovoltaic solar panel and the rotation of the small generator due to the circulation of vapor water with high celerity and it is very clear especially in the last point. However, the decrease of the channels sections between each two panels in the second case (small generator), will increase the celerity of the vapor water. Hence the study of the variation of the electrical power with celerity of the vapor water in the third case (mini turbine) is similar to the second case (small generator), only the values obtained are not similar due to the values of electrical power which are not higher as the second case. Considered the first model; we 
remark that the celerity is constant due to same flow and same section in different panels.

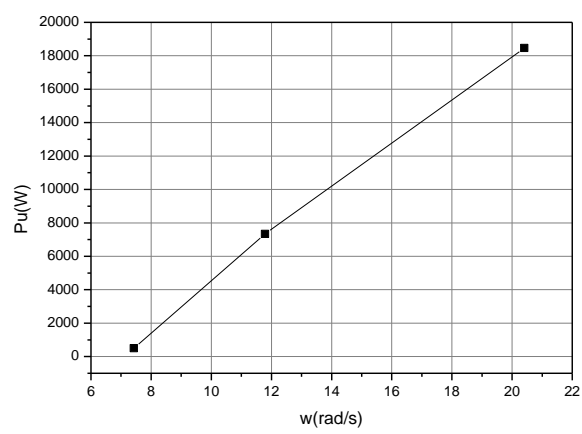

Fig 8: variation of electrical power with angular celerity of selected channels.

Increasing of the electrical power is very clear with increasing of the angular celerity. The rotation of the channel with high angular celerity $(20,40 \mathrm{rad} / \mathrm{s})$ causes production more than $18000 \mathrm{~W}$ of electricity by the small generator.

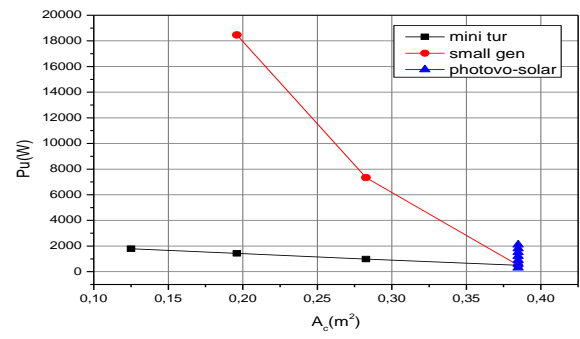

Fig. 9: variation of electrical power with section channels.

Considered the effect of the electrical power produced on the channel section; the fig 9 show that in the second and third case the decreasing of the electrical power (decrease of the celerity of vapor water) because the section of selected channels was increased. The higher value of the section $(0.3848 \mathrm{~m} 2)$ which produced about $499,80 \mathrm{~W}$. however; the using of the small section of section $(0,125 \mathrm{~m} 2)$ can produce about $1784,68 \mathrm{~W}$ in the third case and about $18457,99 \mathrm{~W}$ in the second case.

Tab 1: number of installed panels in different models studied.

\begin{tabular}{|c|c|c|c|c|}
\hline $\begin{array}{l}\text { Proposal } \\
\text { model }\end{array}$ & $\begin{array}{l}\text { Outlet } \\
\text { temperature } \\
\text { of vapor } \\
\text { water }\left({ }^{\circ} \mathrm{C}\right)\end{array}$ & $\begin{array}{l}\text { Electrical } \\
\text { power } \\
\text { produced } \\
\text { (W) }\end{array}$ & $\begin{array}{l}\text { Number of } \\
\text { panels }\end{array}$ & $\begin{array}{l}\text { (Micro- } \\
\text { turbine) } \\
\text { (W) }\end{array}$ \\
\hline $\begin{array}{l}\text { First } \\
\text { model }\end{array}$ & 615 オ & 2100 & 7 & 3000 \\
\hline $\begin{array}{l}\text { Second } \\
\text { model }\end{array}$ & 918 & 18457 & 3 & 3000 \\
\hline $\begin{array}{l}\text { Third } \\
\text { model }\end{array}$ & 622 & 1784 & 4 & 3000 \\
\hline
\end{tabular}

Tab 1; Explain that the best model is the second model because it can product $18457,99 \mathrm{~W}$ by installed of three panels only.

\section{CONCLUSIONS}

Production of electricity by coupling between many kinds of renewable energy was developed in order to increase the amount of electrical power, for using it in intelligent buildings and distributed it in the grid at the same time (produced amount is more than demand amount). The obtained results will inject it for production of hydrogen at different temperature, because the temperature of vapor water arrive until $1726^{\circ} \mathrm{C}$. The amount of electrical power produced by coupling between many sources of renewable energy is more than the amount using only one source. The second model (small generator) can give more amount of energy than the other models. Finally; the next research will be the application of obtained results of the second model (small generator) for production of hydrogen from different sources (at different temperature).

\section{ACKNOWLEDGMENTS}

I acknowledge my parents for all efforts which they given me. The principal author would like to acknowledge Mr. Charles E. Dunlap, Ph.D. for all information's about Publishing Research Articles \& Technical Writing in English. The principal author also gratefully acknowledge of C.A. Associate Program Manager.

\section{REFERENCES}

[1] Nelson A. Kelly Thomas L. Gibson, Increasing the solar photovoltaic energy capture on sunny and cloudy days, Solar Energy Volume 85, Issue 1, January 2011, Pages 111-125.

[2] J. Ordóñez E. Jadraque, J. Alegre, G. Martínez, Analysis of the photovoltaic solar energy capacity of residential rooftops in Andalusia (Spain) Renewable and Sustainable Energy Reviews Volume 14, Issue 7, September 2010, Pages 2122-2130.

[3] C.S. Malvi, D.W. Dixon-Hardy, R. Crook*, Energy balance model of combined photovoltaic solar-thermal system incorporating phase change material Solar Energy volume 85 , Issue 7, July 2011, Pages 1440-1446.

[4] Ezio Sesto!, Claudio Casale",* Exploitation of wind as an energy source to meet the worldÕs electricity demand Journal of Wind Engineeringand Industrial Aerodynamics 74-76 (1998) 375-387.

[5] James R. Salmon*, John L. Walmsley, A two-site correlation model for wind speed, direction and energy estimates Journal of Wind Engineering and Industrial Aerodynamics 79 (1999) 233-268.

[6] Jeffrey Swofford, Michael Slattery, Public attitudes of wind energy in Texas: Local communities in close proximity to wind farms and their effect on decisionmaking, Energy Policy Volume 38, Issue 5, May 2010, Pages 2508-2519.

[7] Stuart J. Self, Bale V. Reddy, Marc A. Rosen, Geothermal heat pump systems: Status review and comparison with other heating options, Applied Energy, journal homepage www.elsevier.com/locate/apenergy, Applied Energy xxx (2012) xxx-xxx.

[8] Onder Ozgener, Arif Hepbasli, Leyla Ozgener, A parametric study on the exergoeconomic assessment of a 
International Journal of Computer Applications (0975 - 8887)

Volume 77-No.14, September 2013

vertical ground-coupled (geothermal) heat pump system Building and Environment 42 (2007) 1503-1509.

[9] Hacene Mahmoudi, Assessment of wind energy to power solar brackish water greenhouse desalination units: A case study from Algeria, Renewable and Sustainable Energy Reviews Volume 13, Issue 8, October 2009, Pages 2149-2155. 